Bolibok, P. (2018). The macroeconomic drivers of household debt-to-income ratio: An evidence from the OECD countries. Copernican Journal of Finance \& Accounting, 7(2), 29-41. http://dx.doi. org/10.12775/CJFA.2018.007

\author{
PIOTR BoliboK* \\ The John Paul II Catholic University of Lublin
}

\title{
THE MACROECONOMIC DRIVERS OF HOUSEHOLD DEBT-TO-INCOME RATIO: AN EVIDENCE FROM THE OECD COUNTRIES
}

Keywords: household indebtedness, determinants of indebtedness, debt-to-income ratio, OECD countries.

J E L Classification: D15, E19, E21, G21, R20.

\begin{abstract}
The paper aims at empirical investigation of the key macroeconomic drivers of household debt-to-income ratio in the OECD countries using a panel data regression analysis to control for the time-invariant country-specific effects. The examined sample covers 31 countries over the period 1996-2015, yielding an unbalanced panel of 439 country-year observations. The results of the fixed-effect panel regression analysis indicate that the household debt-to-income ratio is positively related to the average annual wages, the share of population aged 25-39, the share of population with tertiary education attainment, and the magnitude of the wage-productivity gap. The interest rate and the unemployment rate seem to affect the ratio negatively, although the latter relationship turns out to be statistically insignificant. Contrary to the evidence in the relevant literature, however, after controlling for the country-specific effects, the rate of economic growth and income inequality have been found to affect the debt-to-income ratio negatively. These unexpected results might reflect the likely distortions caused by the recent global financial crisis that has significantly hampered the economic growth and increased the unemployment rate in many developed countries, while the
\end{abstract}

Date of submission: May 25, 2018; date of acceptance: June 29, 2018.

* Contact information: piotr.bolibok@kul.pl, Department of Banking and Finance, The John Paul II Catholic University of Lublin, Al. Racławickie 14, 20-950 Lublin, Poland, phone: +48 8144534 33; ORCID ID: https://orcid.org/0000-0002-5649-181X. 
overall household indebtedness has remained elevated. It is also plausible that a positive impact of income inequality on household indebtedness might be largely limited geographically as it reverses when a larger set of countries is examined.

\section{IIITRODUCTION}

The last couple of decades have witnesses an unprecedented surge in household debt almost all over the world. A key role in this process has been played by housing loans that constitute a vast majority of the outstanding household debt (Finocchiaro, Nilsson, Nyberg \& Soultaneva, 2011, p. 7). Even though directly after the recent global financial crisis some developed countries experienced a modest de-leveraging, their societies still remain heavily indebted. In turn, in the majority of emerging economies household indebtedness continues to grow, however at a reduced pace. Overall, for more than a decade average and median values of the debt-to-income (henceforth: DtI) ratio in the OECD countries have been exceeding 100\% (figure 1).

Figure 1. Average and median DtI ratio in the OECD countries over the period 1996-2015

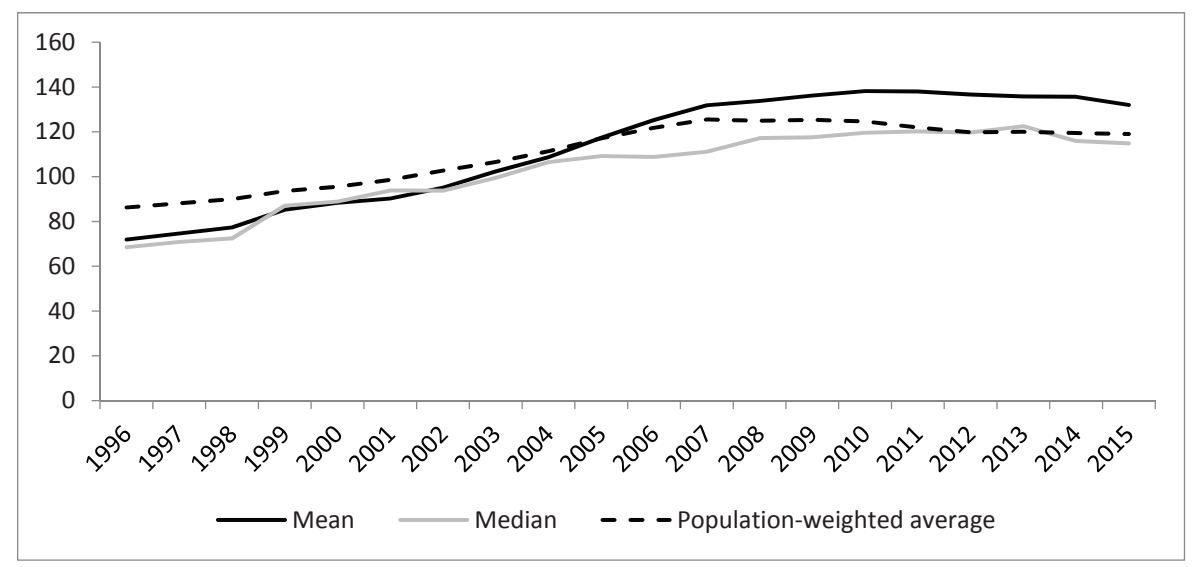

S o u r c e : own elaboration based on OECD (2018) and United Nations (2017).

The relevant literature identifies many factors that might have contributed to the significant growth of household indebtedness. Apart from the consequences of the wide-spread 'easy-money' policy in the period preceding the crisis, i.e. historically low levels of interest rates and an increased availability of 
credit (Taylor, 2009, pp. 1-4; Justiniano, Primiceri \& Tambalotti, 2015, pp. 4-5), the empirical evidence suggests that household indebtedness is dependent on an overall macroeconomic stability (Bloxham \& Kent, 2009, p. 329). Additionally, many studies relate it to the conditions in the housing market, and in particular to the residential property prices (Moore \& Stockhammer, 2018, p. 23), or to the impact of demographic factors, including the structure of age and educational attainment (Magri, 2007, pp. 410-413). Moreover, the studies focusing on the U.S. economy attribute the increase in household debt to stagnant real wages and cutbacks in the welfare state that motivated individuals to simulate their social class by using debt (Barba \& Pivetti, 2009, pp. 121-122; Leicht, 2012, pp. 204-206). Finally, the growth of household borrowing would not be possible without a simultaneous improvement in loan production technology, including in particular various risk management innovations and reductions in distribution costs, nor without a substantial development of financial services marketing and the technology of persuasion (Zinman, 2014, pp. 7-8).

Empirical evidence on the determinants of household indebtedness is based mostly on the analyses of individual countries or relatively narrow panels, which sometimes leads to ambiguous results. By contrast, wide cross-sectional studies seem quite scarce. Given the above, the paper aims at empirical investigation of the key macroeconomic drivers of household indebtedness in the OECD countries over the period 1996-2015, controlling for time-invariant country-specific effects, in search of a more general pattern of this phenomenon.

The remainder of the paper is composed of four sections. The next section provides a review of the relevant literature on the key drivers of household indebtedness. The methodological framework of the study and data selection procedures are described in the third section. Fourth section presents and discusses the key findings. The paper is closed with conclusions and suggestions on the directions of future research.

\section{THE LITERATURE REVIEW}

Under the Modigliani and Brumberg (1954, pp. 388-436) life cycle model of consumption household indebtedness depends on the age structure of the population, the stock of savings, and transitory income shocks. The highest indebtedness is expected for young households, with no or low savings, incomes below the level required to ensure an optimal life-time consumption, and therefore using debt for consumption smoothing. Consistent with this model, 
Thaicharoen, Ariyapruchya, Chuched (2004, pp. 9-10) demonstrate that DtI ratio in Thailand steadily increases until the middle-aged cohorts, beyond which it starts to decline. Additionally, they find that indebtedness is positively related to educational attainment, household size, and housing tenure, while being negatively associated with interest rates. Some further evidence supporting the model can be found in Magri (2007, p. 401) who argues that the demand for bank loans in Italy is determined by the age of household head (reaching its peak at around the age of 30) while the size of a loan determined by household's net wealth and income profile. In turn, a comparative study of the UK, Germany and the U.S. by Brown and Taylor (2008, pp. 633-640) demonstrates that indebtedness is driven mostly by income and the household size, while the impact of household head age differs across countries.

Jacobsen (2004, pp. 108-109) finds the household debt in Norway to be positively related to house prices, the real value of housing stock, the number of house sales, the total wage income in the economy, and the share of university students in the population (as persons with higher education typically take out higher residential loans), whereas bank lending rate and the rate of unemployment affect it negatively.

Dynan and Kohn (2007, pp. 30-32) attribute the growth of household DtI ratio in the U.S. to the combination of growing house prices, declining long-term interest rates, increases in expected incomes, better educational attainment, changes in the age structure of the population, and financial innovation that has enhanced the availability of housing finance and lowered its costs. In turn, Turinetti and Zhuang (2011, pp. 89-91) argue that the U.S. household debt is negatively related to the unemployment rate, interest rate, disposable personal income per capita, the share of retiring population, and educational attainment, while being positively related to housing prices, the share of working-age population, and consumer confidence.

The evidence from emerging economies seems quite similar. A study on the household residential debt in Poland by Bolibok (2015, pp. 604-606) also reports its negative association with market interest rates, relative prices of dwellings, and unemployment rate, as well as a positive impact of population growth (in particular in the cohort of 24-34 years old), and the number of new builds of residential buildings.

Many studies attribute a significant increase in household indebtedness prior to the recent global financial crisis to an overall reduction in macroeconomic volatility. For instance, Bloxham and Kent (2009, pp. 329-330) identify falling 
unemployment, inflation, and interest rates as the key macroeconomic drivers of household DtI ratio in Australia. They also argue that indebtedness is driven by the ageing of the population and the changes in taxes and subsidies determining the attractiveness of residential loans. These findings are partially supported by the results of Meng, Hoang, and Siriwanda (2011, pp. 16-18), who report a positive impact of GDP growth, housing prices, and the number of new dwellings on the stock of Australian household debt. Simultaneously, they find a negative relation of debt with interest rates, unemployment rate, and inflation.

Using a panel of 36 OECD countries over the period 1995-2009 Rubaszek and Serwa (2014, pp. 583-585) demonstrate that the ratio of household debt to GDP is driven by the lending-deposit interest rate spread and both uncertainty and persistence of individual incomes. Additionally, they report a positive impact of GPD per capita, disposable income per capita, and housing prices on household indebtedness, while failing to find a statistically significant influence of unemployment and income inequality.

Numerous studies provide evidence on the interdependence between the house prices and household residential debt resulting from the collateral and wealth effects, under which growing housing prices reduce credit constraints and facilitate mortgage equity withdrawals (see: Godley \& Lavoie, 2007, pp. 40-42). This two-way interaction seems to exist in diverse economies, for instance Finland (Oikarinen, 2009, pp. 751-755), Spain (Gimeno \& Martinez-Carrascal, 2010, pp. 1851-1854), or Norway (Anundsen \& Jansen, 2013, pp. 197-209). According to Turk (2015, pp. 28-29) household debt drives housing prices in the short-run, however, in the long run this relationship reverses and the housing prices become the key driver of the household debt. These findings are in line with those of Moore and Stockhammer (2018, pp. 1-38) who examine a panel of 13 OECD countries over the period 1993-2011, and demonstrate that real residential house prices is the most robust macroeconomic determinant of household debt.

Several studies investigating the household indebtedness in the U.S. suggest that the reasons for its dynamic growth prior to the recent global financial crisis lie in the widening gap between the real rates of growth of productivity and wages, as well as in the considerable retrenchments in the welfare state (Barba \& Pivetti, 2009, p. 114; Stockhammer, 2015, p. 935). The combination of these phenomena created both opportunities and incentives for many American households to use debt as a substitute for insufficient wages, and thus to 'simulate' their social class (Leicht, 2012, pp. 204-206). Increasing income inequality, and in particular the growth of top incomes, drives relatively poor- 
er households to accumulate debt in order to keep consumption at par with their richer peers (Frank, Levine \& Dijk, 2014, p. 63). Some further evidence on the impact of income inequality on the household indebtedness in an international context of the most advanced OECD economies is offered by Klein (2015, pp. 405-410) and Malinen (2016, pp. 317-323).

The review of the relevant literature on the macroeconomic determinants of household indebtedness indicates that the vast majority of prior research is based on the evidence from individual countries, which sometimes leads to ambiguous conclusions, while the available cross-sectional studies are largely limited to the most developed economies. In particular, the evidence based on both broader international data and a wide set of examined explanatory variables remains rather modest. The present study attempts therefore to contribute to the existing literature by filling this gap.

\section{THE RESEARCH METHODOLOGY}

\section{AND THE COURSE OF THE RESEARCH PROCESS}

The empirical evidence in the relevant literature allows to formulate the following set of research hypotheses:

H1: The household DtI ratio in the OECD countries in the long run is positively related to average wages, the rate of economic growth, the share of young and middle-aged population cohorts, the share of population with tertiary education attainment, housing prices, wage-productivity gap, and income inequality.

H2: The household DtI ratio in the OECD countries in the long run is negatively related to interest rate and unemployment rate.

Given a significant cross-sectional heterogeneity in the examined sample and the results of the Hausman specification test, the investigation has been based on a fixed-effect panel data regression analysis. The choice of the explanatory variables employed in the model is largely determined by the availability of data and the pursuance of obtaining a possibly most complete dataset. The variables exhibiting a significant skewness of the distribution have been logtransformed, yielding the following regression model: 
$\ln D t I_{i t}=\beta_{0}+\beta_{1} \cdot \ln A W_{i t}+\beta_{2} \cdot \ln \Delta G D P_{i t}+\beta_{3} \cdot I R_{i t}+\beta_{4} \cdot \ln U R_{i t}+$ $\beta_{5} \cdot \ln P O P_{25-39 i t}+\beta_{6} \cdot T E A_{i t}+\beta_{7} \cdot H R P I_{i t}+\beta_{8} \cdot \ln W P G_{i t}+\beta_{9} \cdot \ln G_{i t}+\alpha_{i}+u_{i t}$

where:

- $\ln D t I_{i t}$ - natural log of the total household debt to net disposable income,

- $\ln A W_{i t}$ - natural log of the average annual wage (constant PPP),

- $\ln \triangle \mathrm{GDP}_{\mathrm{it}}$ - natural log of the rate of growth in real GDP per person (constant PPP),

- $I R_{i t}$ - short-term interest rate,

- $\ln U R_{i t}$ - natural log of the unemployment rate,

- $H_{R P I}$ - housing rent price index,

- $\operatorname{lnPOP}{ }_{25-39_{i t}}$ - natural $\log$ of the share of population aged 25-39,

- TEA $A_{i t}$ - the share of population aged 25-64 with tertiary education attainment,

- $\ln W P G_{i t}$ - wage-productivity gap measured as the natural log of the relation of GDP per person employed to average annual wage,

- $\ln G_{i t}$ - natural log of the Gini coefficient for net disposable income,

- $\beta_{1}, \beta_{2}, \ldots, \beta_{8}$ - regression coefficients,

- $\beta_{0}$ - intercept,

- $\alpha_{i}$ - unknown intercept for each country,

- $i$ - country,

- $t$-year,

- $u_{i t}$ - error term.

As regards the expected signs of the regression coefficients, both higher average wages and faster GDP growth should generally fuel borrowing, as they improve households' creditworthiness and boost their optimism about the future income prospects, allowing them to take on larger loans. The estimates of the coefficients $\beta_{1}$ and $\beta_{2}$ are, therefore, expected to be positive. However, it is possible that they become negative if household incomes should grow faster than the stock of debt.

The interest rate is expected to be inversely related to the DtI ratio resulting in a negative estimate of the coefficient $\beta_{3}$. Although the prevalence of mortgage debt suggests using a long-term interest rate as an explanatory variable, given a strong positive correlation between long and short-term interest rates, and a much higher number of available observations for the latter one, it has been employed in the model. 
The estimate of the coefficient $\beta_{4}$ is expected to be negative since growing unemployment makes households' future incomes less predictable thus discouraging them from taking on additional debt.

According to the available evidence, the highest household indebtedness is expected for the middle-aged cohorts and for the persons with higher education attainment, which suggests positive estimates of the coefficients $\beta_{5}$ and $\beta_{6}$.

Given that the growth of housing prices fuels household borrowing, while their decrease discourages it, the estimated value of the coefficient $\beta_{7}$ is expected to be positive. Again, in order to use a possibly most complete time series, the housing rental price index has been employed in the model as an explanatory variable.

Finally, both wider wage-productivity gaps and more unequal distribution of incomes might encourage poorer households to fuel consumption with debt in order to reduce the distance from their richer peers, which allows to expect positive estimates of the coefficients $\beta_{8}$ and $\beta_{9}$.

The research has been designed to examine all OECD member countries over the period 1996-2015. The data employed in the analysis have been extracted from the OECD.Stat database (OECD, 2018) and the World Population Prospects database by the United Nations (2017). Due to incompleteness of data, 4 countries (Israel, Mexico, New Zealand, and Turkey) have been dropped from the sample, yielding the final unbalanced panel of 31 countries and 439 country-year observations.

\section{RESULTS}

The results of the estimation of the constructed regression model are reported in table 1.

Table 1. Estimations of the fixed-effect panel regression model

\begin{tabular}{|c|c|c|c|c|c|c|}
\hline \multicolumn{7}{|c|}{$\begin{array}{c}\text { Model: } \ln D t I_{i t}=\beta_{0}+\beta_{1} \cdot \ln A W_{i t}+\beta_{2} \cdot \ln \Delta G D P_{i t}+\beta_{3} \cdot I R_{i t}+\beta_{4} \cdot \ln U R_{i t}+\beta_{5} \cdot \ln P O P_{25-39_{i t}}+ \\
\beta_{6} \cdot T E A_{i t}+\beta_{7} \cdot H R P I_{i t}+\beta_{8} \cdot \ln W P G_{i t}+\beta_{9} \cdot \ln G_{i t}+\alpha_{i}+u_{i t}\end{array}$} \\
\hline Estimate & Value & Std. error & $\mathbf{t}$ & $p$-value & \multicolumn{2}{|c|}{$95 \%$ conf. interval } \\
\hline$\beta_{0}$ & -11.453 & 1.990 & -5.76 & 0.000 & -15.366 & -7.541 \\
\hline$\beta_{1}$ & 1.384 & 0.172 & 8.04 & 0.000 & 1.046 & 1.723 \\
\hline$\beta_{2}$ & -1.678 & 0.286 & -5.87 & 0.000 & -2.240 & -1.116 \\
\hline
\end{tabular}


Table 1. Estimations of the fixed-effect panel regression model

\begin{tabular}{|c|c|c|c|c|c|c|}
\hline \multicolumn{7}{|c|}{$\begin{array}{c}\text { Model: } \ln D t I_{i t}=\beta_{0}+\beta_{1} \cdot \ln A W_{i t}+\beta_{2} \cdot \ln \Delta G D P_{i t}+\beta_{3} \cdot I R_{i t}+\beta_{4} \cdot \ln U R_{i t}+\beta_{5} \cdot \ln P O P_{25-39_{i t}}+ \\
\beta_{6} \cdot T E A_{i t}+\beta_{7} \cdot H R P I_{i t}+\beta_{8} \cdot \ln W P G_{i t}+\beta_{9} \cdot \ln G_{i t}+\alpha_{i}+u_{i t}\end{array}$} \\
\hline Estimate & Value & Std. error & $\mathbf{t}$ & $p$-value & \multicolumn{2}{|c|}{$95 \%$ conf. interval } \\
\hline$\beta_{3}$ & -0.019 & 0.005 & -4.16 & 0.000 & -0.028 & -0.010 \\
\hline$\beta_{4}$ & -0.013 & 0.034 & -0.40 & 0.691 & -0.079 & 0.053 \\
\hline$\beta_{5}$ & 0.450 & 0.183 & 2.46 & 0.014 & 0.090 & 0.811 \\
\hline$\beta_{6}$ & 0.014 & 0.003 & 3.79 & 0.000 & 0.007 & 0.021 \\
\hline$\beta_{7}$ & 0.002 & 0.001 & 2.35 & 0.019 & 0.000 & 0.004 \\
\hline$\beta_{8}$ & 1.066 & 0.251 & 4.25 & 0.000 & 0.573 & 1.558 \\
\hline$\beta_{9}$ & -0.872 & 0.225 & -3.87 & 0.000 & -15.366 & -7.541 \\
\hline $\begin{array}{ll}\mathrm{R}^{2} \text { : } & \\
- & \text { within } \\
- & \text { between } \\
- & \text { overall }\end{array}$ & $\begin{array}{l}0.661 \\
0.462 \\
0.477\end{array}$ & & & & & \\
\hline$F(9,399)$ & 86.52 & & & 0.000 & & \\
\hline rho & 0.892 & & & & & \\
\hline N & 439 & & & & & \\
\hline Number of groups & 31 & & & & & \\
\hline $\begin{array}{l}\text { Observations per group } \\
-\quad \min \\
-\quad \max \\
-\quad \text { average }\end{array}$ & $\begin{array}{r}7 \\
20 \\
14.2\end{array}$ & & & & & \\
\hline
\end{tabular}

S o u r c e : own elaboration.

The estimated model is statistically significant at all conventional levels. The variance of the explanatory variables has been able to explain over $66 \%$ of variation in the household DtI ratio within the analysed countries. The estimated value of the parameter rho indicates a strong heterogeneity in the examined sample, as over $89 \%$ of the variance in DtI has been attributable to the differences across countries.

The majority of the estimated regression coefficients have the expected signs and are statistically significant at the 0.05 level. The results of the estimation indicate that after controlling for the time-invariant country-specific factors, the household DtI ratio in the OECD countries is positively related to the 
average annual wages, the share of population aged 25-39, the share of population with tertiary education attainment, and the magnitude of the wage-productivity gap, while being negatively associated with the interest rate.

The regression coefficient for the unemployment rate $\left(\beta_{5}\right)$, although negative as expected, is statistically insignificant, which seems consistent with the findings of Rubaszek and Serwa (2014, p. 584). Contrary to ex-ante expectations, however, the estimated coefficients $\beta_{2}$ and $\beta_{9}$ have turned out to be negative. It appears therefore, that after controlling for the country-specific effects, the rate of economic growth and income inequality influence the household DtI ratio negatively.

The statistical insignificance of the relationship between household indebtedness and unemployment, as well as the unexpected negative impact of economic growth might be partially explained by the likely distortions caused by the recent global financial crisis, in the aftermath of which many developed countries have suffered a rising unemployment combined with a negative or stagnant growth while households have struggled to deleverage, and the overall DtI ratio has remained elevated. In turn, the negative estimate of the coefficient $\beta_{9}$ suggests that a positive relationship between income inequality and household debt might in fact be largely limited geographically, as it actually becomes reversed in a broader panel of countries.

\section{ConcLusions}

The results of the research largely support both hypotheses of the present study. Some of the findings, however, have turned out to be surprising. Consistent with the conclusions of the prior investigations, the household DtI ratio in the OECD countries appears to be positively related to the average annual wages, the share of population aged 25-39, the share of population with tertiary education attainment, and the magnitude of the wage-productivity gap. In turn, the interest rates and the unemployment rate seem to affect the ratio negatively, although the latter relationship is statistically insignificant. Therefore, the long-run cross-sectional evidence confirms the impact of the majority of macroeconomic household debt drivers identified in the relevant literature.

Unexpectedly, after controlling for the country-specific effects, the rate of economic growth and income inequality have been found to affect the DtI ratio negatively. One of the possible explanations of the former relationship is the impact of the recent global financial crisis that has significantly hampered the 
economic growth while the household indebtedness has not adjusted accordingly. The cross-sectional evidence suggests that the responsiveness of household debt to the course of the business cycle is largely asymmetric. An intensified borrowing during the times of expansion leads to accumulation of debt which in turn becomes difficult to reduce when the economy turns down and households struggle to delever. Moreover, it is also likely that in some countries a faster economic growth might in fact decrease the demand for borrowing, as households find it easier to cover their expenses with incomes, instead of using debt.

The negative relationship between income inequality and indebtedness suggests that a positive association between these variables reported by some prior studies might in fact be a country-specific phenomenon, likely driven by cultural factors. It seems in the cross-section an overall increase in household DtI ratio in the long run occurs along with a simultaneous reduction in income inequality. It is also possible that the relationship between income inequality and household indebtedness is non-linear, being negative when the distribution of incomes is more equal, but turning into positive when the gap between poorer and richer households begins to widen beyond a certain threshold.

Finally, the results of the study suggest that some of the linkages between the household DtI ratio and its determinants in the examined countries could likely become distorted by the impact of the recent global financial crisis. Therefore, the future research might attempt to explore these distortions in detail.

\section{REFERENCES}

Anundsen, A.K., \& Jansen, E.S. (2013). Self-reinforcing effects between housing prices and credit. Journal of Housing Economics, 22(3), 192-212. http://dx.doi. org/10.1016/j.jhe.2013.07.001.

Barba, A., \& Pivetti, M. (2009). Rising household debt: Its causes and macroeconomic implications - a long-period analysis. Cambridge Journal of Economics, 33, 113-137.

Bloxham, P., \& Kent, C. (2009). Household indebtedness. The Australian Economic Review, 42(3), 327-339.

Bolibok, P. (2015). An empirical evaluation of the demand-side drivers of household residential debt: The case of Poland. Finanse, Rynki Finansowe, Ubezpieczenia, (Finance, Financial Markets, Insurance.) 74(2), 597-608.

Brown, S., \& Taylor, K. (2008). Household debt and financial assets: Evidence from Germany, Great Britain and the US. Journal of the Royal Statistical Society: Series $A$ (Statistics in Society), 171(3), 615-643. http://dx.doi.org/10.1111/j.1467985X.2007.00531.x. 
Dynan, K.E., \& Kohn, D.L. (2007). The rise in U.S. household indebtedness: Causes and consequences. FEDS Working Paper, 2007-37. http://dx.doi.org/10.2139/ ssrn.1019052.

Finocchiaro, D., Nilsson, C., Nyberg, D., \& Soultaneva, A. (2011). Household indebtedness, house prices and the macroeconomy: a review of the literature. Sverige Riksbank Economic Review, 1, 6-28.

Frank, R.H., Levine, A.S., \& Dijk, O. (2014). Expenditure Cascades. Review of Behavioral Economics, 1(1-2), 55-73. http://dx.doi.org/10.1561/105.00000003.

Gimeno, R., \& Martinez-Carrascal, C. (2010). The relationship between house prices and house purchase loans: The Spanish case. Journal of Banking and Finance, 34(8), 1849-1855. http://dx.doi.org/10.1016/j.jbankfin.2009.12.011.

Godley, W., \& Lavoie, M. (2007). Monetary Economics. New York: Palgrave Macmillan.

Jacobsen, D.H. (2004). What influences the growth of household debt? Norges Bank Economic Bulletin, Q3, 103-111.

Justiniano, A., Primiceri, G.E., \& Tambalotti, A. (2015). Credit supply and the housing boom. NBER Working Paper, 20874. http://dx.doi.org/10.3386/w20874.

Klein, M. (2015). Inequality and household debt: a panel cointegration analysis. Empirica, 42, 391-412. http://dx.doi.org/10.1007/s10663-015-9281-7.

Leicht, K.T. (2012). Borrowing to the brink. Consumer debt in America. In K. Porter, E. Warren (Eds.). Broke. How debt bankrupts the middle class. Stanford: Stanford University Press.

Magri, S. (2007). Italian households' debt: The participation to the debt market and the size of the loan. Empirical Economics, 33, 401-426.

Malinen, T. (2016). Does income inequality contribute to credit cycles? Journal of Economic Inequality, 14(3), 309-325. http://dx.doi.og/10.1007/s10888-016-9334-6.

Meng, S., Hoang, N.T., \& Siriwardana, M. (2011). The determinants of Australian household debt: A macro-level study. Working Papers Business, Economics and Public Policy, 2011-4.

Modigliani, F., \& Brumberg, R. (1954). Utility Analysis and the Consumption Function: An Interpretation of Cross-section Data. In K. Kurihara (Ed.). Post Keynesian Economics. New Brunswick: Rutgers University Press.

Moore, G.L., \& Stockhammer, E. (2018). The drivers of household indebtedness re-considered: an empirical evaluation of competing arguments on the macroeconomic determinants of household indebtedness in OECD countries. Working Papers from Post Keynesian Economics Society, 1803.

OECD (2018). OECD.Stat, http://stats.oecd.org (accessed: 20.04.2018).

Oikarinen, E. (2009). Interaction between housing prices and household borrowing: The Finnish case. Journal of Banking and Finance, 33(4), 747-756. http://dx.doi. org/10.1016/j.jbankfin.2008.11.004.

Rubaszek, M., \& Serwa, D. (2014). Determinants of credit to households: An approach using the life-cycle model. Economic Systems, 38(4), 572-587. http://dx.doi. org/10.1016/j.ecosys.2014.05.004.

Stockhammer, E. (2015). Rising inequality as a cause of the present crisis. Cambridge Journal of Economics, 39(3), 935-958. http://dx.doi.org/10.1093/cje/bet052. 
Taylor, J.B. (2009). The Financial Crisis and the Policy Responses: An Empirical Analysis of What Went Wrong. NBER Working Paper, 14631. http://dx.doi.org/10.3386/ w14631.

Thaicharoen, V., Ariyapruchya, K., \& Chuched, T. (2004). Rising Thai household debt: Assessing the risks and policy implications. Working Papers from Monetary Policy Group, 2004-01.

Turinetti, E., \& Zhuang, H. (2011). Exploring Determinants of U.S. Household Debt. Journal of Applied Business Research, 27(6), 85-91. http://dx.doi.org/10.19030/jabr. v27i6.6468.

Turk, R. A. (2015). Housing Price and Household Debt Interactions in Sweden. IMF Working Paper, 15/276. http://dx.doi.org/10.5089/9781513586205.001.

United Nations (2017). World Population Prospects, http://esa.un.org/unpd/wpp (accessed: 20.04.2018).

Zinman, J. (2014). Household debt: Facts, puzzles, theories, and policies. NBER Working Paper, 20496. http://dx.doi.org/10.3386/w20496. 
